\title{
The Influence of Organization Participation and Learning Styles on Students' Academic Achievement
}

\author{
Isra Dwi Ningrum ${ }^{1}$, Yulhendri ${ }^{2}$, Marwan ${ }^{3}$, Rose Rahmidani ${ }^{4}$ \\ ${ }^{1}$ Faculty of Economics, Universitas Negeri Padang, Padang, Indonesia \\ $\square$ (e-mail) isradwiningrum@yahoo.co.id \\ ${ }^{2}$ Dept. of Economics, Faculty of Economics, Universitas Negeri Padang, Padang, Indonesia \\ $\square$ (e-mail) yulhendrisutan@yahoo.co.id \\ ${ }^{3}$ Dept. of Economics, Faculty of Economics, Universitas Negeri Padang, Padang, Indonesia \\ $\triangle$ (e-mail) marwan@fe.unp.ac.id \\ ${ }^{4}$ Dept. of Economics, Faculty of Economics, Universitas Negeri Padang, Padang, Indonesia \\ $\square$ (e-mail) rose_rahmidani@fe.unp.ac.id
}

\begin{abstract}
The study was conducted to determine the influence of the activeness in organization and learning style toward students' academic achievement particularly at the Faculty of Economics, State University of Padang. This study is a descriptive associative study. Students who are active in organization within period 2015/2016 in the Faculty of Economics were about 250 students. Slovin formula was used to determine the sample size and probability sampling was used for the technique of sampling. The samples or dataset are students who are active in organization at the Faculty of Economics as many as 154 students. Questionnaire and documentation were used to collect the data. The data were processed using descriptive and inferential analyses. The results of the study are as follows. First, the activeness in organization significantly influences the student academic achievement. Second, learning style influences significantly the student academic achievement. Finally, the students' organization participation and learning style influence significantly the student academic achievement.
\end{abstract}

Keywords: students' organization participation, learning style, students' academic achievement

\section{Introduction}

Education is an attempt to prepare an individual to become a more mature human that is shaping the one to be able to fulfill the responsibilities both intellectual and moral (SISDIKNAS) No. 20 Year 2003. University is one of formal education that is assigned and responsible to prepare students in accordance to the national educational system in achieving academic achievement. Academic achievement (both in traditional and online learning settings) can be generally defined as achieving certain results in online tasks, exams, subjects, or titles, and is usually expressed in terms of numerical or average values (GPA) (Richardson, Abraham, \& Bond, 2012).

Sobur (as cited in Sahputra, 2009, 161) stated that academic achievement is not caused by the growing process, but the existence of learning situation. The manifestation of the result can be either oral or written, there is a great tendency to repeat when the skill was satisfying a need and can be measured or assessed using standardized tests (Ahmadi, 2007, 50).

The factors that affect the achievement of a student is the activeness in organization and the learning style. Organizational activeness is an activity performed by two or more people in a system (Pabundu, 2010,3). Student who is active in organization both physical and non-physical activity with indicators of physical involvement and mental involvement (Kurniawati, 2009, 12; Sardiman, 2001, 98). Physical involvement consists of visual activity, oral activity, listening activity and Metrix activity (Nurcahya, 2006, 37). Visual activities that include viewing, observing, and reading any 
activities that exists in student organizations, by involving in visual activities automatically students will learn from the surrounding organizational environment where they join in. Oral activities could be exemplified as expressing opinions, questions and ideas. Listening activities are indicated by the willingness or attention of the involved students to listen to discussion or instruction in that organization. Metrix activities could be exemplified by the direct involvement of students in the student organizations, such as conducting experiments, engaging in activities that are the workplan of organization.

The facts that happened in the real world showing most of students who are active in organizational activities have average GPA lower than 3.00. Based on the interview with one of the organizer of an organization in the Faculty of Economics, Universitas Negeri Padang, on Thursday, 12 March 2015, the lower average GPA was due to the presence to lectures, either not punctual, breaking the rules, lack of activeness in lecture, not punctual finishing the tasks given by lecturer, lack of concern to campus facilities and problem with interaction both to the lecturers and other students.

Here in the table below is the average academic achievement of students at the faculty of economics especially those who have the GPA below 3.00. The table represents the students who are active in organizational activities. For more details can be seen in table 1 below.

Table 1 The academic achievement of students who are active in organizational activities with GPA under 3.00

\begin{tabular}{lcc}
\hline \multicolumn{1}{c}{ Organization Name } & GPA $<3.00$ & $\begin{array}{c}\text { The Lowest } \\
\text { GPA }\end{array}$ \\
\hline BPM & 6 & 2,65 \\
BEM & 13 & 2,44 \\
Accounting students' & 14 & 2,46 \\
$\begin{array}{l}\text { association } \\
\text { Economics Education } \\
\text { students' association }\end{array}$ & 7 & 2,32 \\
$\begin{array}{l}\text { Management students' } \\
\text { association }\end{array}$ & 14 & 2,29 \\
$\begin{array}{l}\text { Economics students' } \\
\text { association }\end{array}$ & 8 & 2,31 \\
$\begin{array}{l}\text { Accounting diploma } \\
\text { students' association }\end{array}$ & 10 & 2,31 \\
$\begin{array}{l}\text { Management diploma } \\
\text { students' association }\end{array}$ & 9 & 2,5 \\
\hline Total & 81 & \\
\hline \multicolumn{1}{c}{ Source: Universitas Negeri Padang }
\end{tabular}

The data based on the table above says that the students' lowest GPA was 2.29. It clearly says that not everyone who are active in the students' organizational activities have GPA higher than 3.00 with some of them have GPA lower than minimum GPA.

In addition to students' organization participation that can affect student's GPA, learning style is also a factor that affects student's GPA. Each activist has different learning styles to achieve the learning objectives such as kinesthetic, auditoria, and visual learning style. Lecture style that suits the students in the class could improve the student's will to study. Learning style is a combination of how students capture and absorb information of the materials, which are visual, auditoria, and kinesthetic learning type (Dalyono, 2010).

According to James and Blank (1993) learning styles can be defined as a complex way in which learners are most efficient and most effective at seeing, processing, storing and remembering what is learned. Honey and Mumford (1992) have defined learning styles as attitudes and behaviors that determine the learning style that is preferred by individual. Rafy $(2009,288)$ argued that learning styles are a consistent way of doing things in capturing stimuli or information on how to remember or think and solve problems. 
According to Felder et al. (1991), who list and serialist are known as global and sequential; while verbalize and imager are known as verbal and visual. Learning style is the way he reacts, (Nasution, 2011, 93) absorbs, and organizes and processes information (DePorter \& Hernacki, 2000, 110). This opinion is supported by Fleming and Mills that the learning style is a tendency of students who are active in organization to adapt certain strategies in learning as a form of responsibility to get a learning approach in accordance with the demands of learning in the classroom/school and the demands of the subjects.

In general, human learning styles are divided into three major groups, namely visual, auditorial and kinesthetic styles. Visual learning style is the style of learning by looking, observing, looking at, and the like. Auditorial style is learning style by listening. Whereas, the kinesthetic learning style is the learning style by moving, working, and touching.

Students who understand the tendency of a good learning style will have a high GPA (Pujiningsih, 2009). High academic achievement, showing the achievement or student learning progress cumulatively from the first to the last semester that has been taken (Nadziruddin, 2007; Dikti, 2003). This statement is supported by Tanta (2010) concluded as much as $73 \%$ of learning styles indicate the influence of learning styles on student learning outcomes because the tendency of satisfaction of most students is measured from passing the course than the understanding of the content of the course.

Other studies conducted by Bire, Geradus, and Bire (2014) suggest that visual learning style $\left(\mathrm{X}_{1}\right)$, auditorial learning style $\left(X_{2}\right)$, and kinesthetic learning style $\left(X_{3}\right)$ together have a positive and significant influence on the Student Achievement $(\mathrm{Y})$ variable at the Building Department of SMK Negeri 5 Kupang in year 2013/2014.

Based on the description above, this study is interested in examining the influence of students' organization participation and learning style toward student's academic achievement at the faculty of economics, Universitas Negeri Padang.

\section{Methods}

This study is a descriptive associative research to examine the influence of activeness of organization and learning style to academic achievement at The Faculty of Economics, Universitas Negeri Padang State University of Padang. The population of this research was students who were actively participate in organizations with the total of 250 students. The sample of this study was 154 students from various organizations participation such as Students' Senate, Students' Executive Body, and Students Association Body.

The data were collected by a survey questionnaire and documentation. The data set used in this study was the primary data in form of questionnaires responses related to the questions about organization participation and learning styles. The secondary data were data of total activists and their GPA at Faculty of Economics, obtained from The Computer/Data Center. The research data were analyzed by using multiple regression analysis.

An instrument test was done to determine its validity and reliability. The validity test was done by calculating the correlation of each statement item with total score of observation by using product moment correlation formula. A pilot test was carried out to 30 students of Faculty of Mathematics and Natural Sciences. There results revealed that, of all the questionnaire item, there were 7 invalid items, no item was fixed and 7 items were eliminated.

A reliability test was also conducted to ensure the questionnaire can give the same results when given to individuals in different times. The reliability was checked by using Cronbach alpha (Idris, $2008,8)$ because the questions are in the form of a description. The results of the reliability test showed that the organization participation variable has a Cronbach alpha of 0.738 which was in very high category. The learning style variable was also in very high category with Cronbach alpha of 0.743. This indicated that the instrument was reliable. 


\section{Results and Discussion}

Multiple regression analysis was used to see the effect of students' organization participation and learning styles on student achievement index at The Faculty of Economics, Universitas Negeri Padang. After conducting normality, heteroscedasticity and multicollinearity tests, this study continued with the multiple regression analysis.

Table 2 Results of multiple regression analysis

\begin{tabular}{lccc}
\hline Source & Coefficient & T & Sig. \\
\hline Constants & 2.554 & - & - \\
\hline $\begin{array}{l}\text { Activeness in } \\
\text { organization }\left(\mathrm{X}_{1}\right)\end{array}$ & 0.010 & 1.931 & 0.105 \\
\hline Learning Style $\left(\mathrm{X}_{2}\right)$ & -0.001 & -0.325 & 0.746 \\
\hline Source: SPSS results, 2016 & \multicolumn{2}{c}{$\mathrm{Y}=\mathrm{a}+\mathrm{b}_{1} \mathrm{X}_{1}+\mathrm{b}_{2} \mathrm{X}_{2}$} & \\
& $\mathrm{Y}=2.554+0.010 \mathrm{X}_{1}-0.001 \mathrm{X}_{2}$ &
\end{tabular}

The constant value of regression equation is 2.554. The contribution of all independent variables to the dependent variable is very low and the relationship is very weak if $\mathrm{r}^{2}$ approaches 0 , if $\mathrm{r}^{2}$ approaches 1 , then the contribution of all independent variables to the dependent variable is very high and the relationship tends strongly and near perfect. The value of $\mathrm{r}$ (double correlation) coefficient is 0.178 and the value of $\mathrm{r}^{2}$ is 0.032 . Thus, the contribution of all independent variables to the dependent variable is $3.2 \%$.

The F-test was conducted to get to know whether all independent variables, namely, students' organization participation $\left(\mathrm{X}_{1}\right)$ and learning styles $\left(\mathrm{X}_{2}\right)$ have a significant influence on the dependent variable of academic achievement $(\mathrm{Y})$. The significance level is $8,9 \%$ and value for F-arithmetic is 2.457. This trend shows that the significance value is greater than 0.10 . Hence, it can be concluded that organization participation $\left(X_{1}\right)$ and learning styles $\left(X_{2}\right)$ have a significant influence on academic achievement $(\mathrm{Y})$ at Faculty of Economics, Universitas Negeri Padang by $8.9 \%$.

The t-test aims to see the effect of independent variables consisting of organization participation $\left(\mathrm{X}_{1}\right)$ and learning styles $\left(\mathrm{X}_{2}\right)$ on academic achievement $(\mathrm{Y})$. The results in Table 2 show that $\mathrm{t}$-counts value of the influence of organization participation $\left(\mathrm{X}_{1}\right)$ on academic achievement $(\mathrm{Y})$ is 1.931 while the value of $\mathrm{t}$ table is $1.980(\mathrm{dk}=\mathrm{NK}-1=154-2-1=151)$. The significance level of organization participation $\left(\mathrm{X}_{1}\right)$ was 0.105 . As for the learning style $t$ value $\left(\mathrm{X}_{2}\right)$ to academic achievement $(\mathrm{Y})=-0.325$ and $t$ table $=1.980$ and sig. learning style variable $(\mathrm{X} 2)$ to achievement of academic $(\mathrm{Y})$ equal to 0.746 .

Then it can be concluded that organization participation $\left(X_{1}\right)$ has a significant effect of $5.5 \%$ on academic achievement $(Y)$. Moreover, learning style $\left(X_{2}\right)$ has a significant effect of $74.6 \%$ on academic achievement (Y).

\section{The Influence of The Activeness in Organization on Student Achievement Index}

Activeness in organization has 2 indicators which are physical involvement and mental involvement. This is in accordance with the notion of involvement or participation according to (Sardirman, 2001, 98) is "an activity that is either physical or mental, that is, do and think as an inseparable series".

Implemented in organization members who want to prove that their decision to engage in the organization is true despite ultimately sacrificing their own performance and adversely affecting the organization in terms of workload, due to other priority which is academic.

Based on the results of hypothesis testing that has been conducted, it clearly can be seen that the activeness in organization effects significantly on the student academic achievement at the Faculty of 
Economics, State University of Padang. This is in accordance with the research conducted by Triana (2013) which states that there is a positive influence between the activeness in the organization to the achievement of students at the Department of Geographic Education in academic year 2008/2009 at State University of Yogyakarta.

in line with research conducted by Syofyan (2010) which states that there is a significant influence between participation in student organizations and interpersonal communication on student achievement. This strengthens the theory submitted by some authors that student organizations in college is a place to enrich self-development to get a wider insight, improvement of knowledge and integrity of student personalities. Being active in the organization, students can gain a learning experience and insights that are not available in the lecture hall.

\section{The Influence of Learning Styles on Student Achievement Index}

Learning styles include 3 indicators namely visual, auditoria, and kinesthetic, these factors generally influence student's learning process. This is supported by Howard Gardner's saying modality of learning can be characterized into auditory, visual, reading, and kinesthetic learning styles. This indicator is what the author refers as variable $\mathrm{X} 2$ in this study about the learning style of student achievement index at the Faculty of Economics, State University of Padang.

The results of the above research, supported by conducting some question and answer activities with a number of students about the application of their learning styles in the learning process. Some of them are less optimized their learning style because they are less able to apply the way of understanding the material based on learning style. As the result, students do not understand the given lessons and also do not understand what is delivered by the lecturer during the teaching and learning process took place. In the end, it will impact the student achievement index.

This is in accordance with a research conducted by Purwiana and Rohayati (2016) which shows that the result of learning style and student learning environment study has an effect on student achievement at the Faculty of Economics, Accounting Department, State University of Surabaya. In line with research conducted by Tanta (2010) which states the learning style significantly affects the results of students at Biology Education Study Program in General Biology course.

So, the hypothesis proposed by the researcher is accepted based on the result of the analysis that has been conducted. In this study, the categorization that the learning style of the students of economic education program in State University of Padang is quite good and has an influence on student learning outcomes because the tendency of satisfaction of most students is measured bypassing the course rather than the comprehension of the content of the course. As a result of the above reasons that after completion of a course, students tend to forget what they learnt.

\section{The Influence of The Activeness in Organization and Learning Style on Student Achievement Index}

Based on the analysis of hypothesis test, can be seen that the activeness in organization and learning style together have a significant influence on the academic achievement at Faculty of Economics, State University of Padang. This means closely related to the two main tasks that must be executed by students which are active both in lecture and organization. Students who are active in organization, despite the obligatory to attend the lecture they also have to run the workplan appointed to them by the organization, thus requiring the proper time scheduling so that both can run in synergy.

Students at the Faculty of Economics, State University of Padang in extracurricular activities are quite active in following the activities held within the organization. Indirectly they have chosen extracurricular according to their interests and talents. Therefore, students are required to be active both in academic and non-academic aspects, because if the student is lazy and just relying on what is told by lecturers or chairman of the organization then the result is not necessarily satisfactory. 
As an activist and also a student, learning styles are one of the keys to level up the performance in work, on campus and in interpersonal situations. There are two main categories that experts have agreed on of how we learn. First, how we absorb information easily (modalities) and second, the way we organize and process that information (brain dominance) (DePorter and Hernacki, 2013: 110).

In whole or partially, the activeness in organization and learning styles provide a meaningful relationship to the student academic achievement at the Faculty of Economics, State University of Padang, both on mental and physical involvement as well as visual, auditoria, and kinesthetic learning styles. This shows that the activeness in organization and learning styles provide a meaningful relationship to academic achievement.

The achievement index achieved by the students is not fully determined by how big the student's activeness in organization is, but also determined by the student's own learning style, this is where the smart student will easily be able to capture the lesson given by the lecturer. Hence in this research both the activeness in organization (X1) and learning style (X2) have a significant influence on Student Achievement Index $(\mathrm{Y})$ at The Faculty of Economics in State University of Padang.

\section{Conclusions}

1. The activeness in organization significantly influences student achievement index. The results of this study indicate that the higher the activity of student in organization, the higher it will affect the student achievement index at the Faculty of Economics, State University of Padang.

2. Learning Style significantly influences student achievement index. The results of this study indicate that the higher the learning style of students then the higher it will affect the student achievement index at the Faculty of Economics, State University of Padang.

3. Together the activeness in organization and learning style influence student academic achievement index at the Faculty of Economics, State University of Padang.

Based on the results of research and conclusions that have been describe by the researcher, in order to improve the academic achievement index of Students Faculty of Economics, State University of Padang better for the future the authors suggest:

1. To the Students of Faculty of Economics, State University of Padang, it is expected to be able to improve their learning achievement by increasing organization involvement, actively involved in activities that exist in student organizations. It because based on interviews and research that the authors conduct, and the environment of related theories, the involvement of students in the organization contributes a lot to the learning achievement.

2. To the students of Faculty of Economics, State University of Padang, it is expected to be able to improve the achievement index by increasing the Learning Style. Students as individuals have three learning styles that support each other despite the tendency of one type. There are six methods to help students maximize learning styles. First, identify individual learning style types, visual, auditorial, or kinesthetic types. Second, identify their individual learning styles, so that students able to determine the proper and effective way of learning. Third, people learn in different ways and all ways equally well,. Fourth, fill yourself with the chance to succeed in the learning style. Fifth, detect the best potential that need to develop. Sixth, use a learning style strategy to master opportunities and other concepts. Therefore, it is expected that students can combine these three learning styles so that the impact will improve academic achievement.

3. This study is still limited to a small scope of discussion and it is expected to the next researchers to:

a. Develop research on other factors of activeness in organization that can affect student academic achievement, such as achievement motivation, confidence and others.

b. Develop research on learning styles, discuss more broadly about other factors that may affect students' achievement, such as Impact of Participant Modeling Strategy, The Effectiveness of PQ4R Learning Strategy (Preview, Question, Read, Reflect, Recite, Review), The Implementation of Learning Model, The Implementation of Project Methods and others. 


\section{References}

Ahmadi, Abu. (2007). Psikologi Sosial. Rineka Cipta. Jakarta.

Bire, Arylien Ludji, Geradus, Uda, \& Bire, Josua. (2014). Pengaruh gaya belajar visual, auditorial, dan kinestetik terhadap prestasi belajar siswa. Universitas Nusa Cendana.

Coleman, James S., Ernest Q. Campbell, Carol J. Hobson, James McPartland, Alexander M. Mood, Frederic D. Weinfeld, and Robert L. York. (1966). Equality of Educational Opportunity. Washington, D.C.: U.S. Department of Health, Education, and Welfare, Office of Education.

Dalyono. (2010). Psikologi Pendidikan. Jakarta: Bumi Aksara.

DePorter, Bobbi, \& Hernacki, Mike. (2000). Quantum Learning: Membiasakan Belajar Nyaman dan Menyenangkan. Bandung: Kaifa.

Felder, R. M., \& Solomon, B. (1991). Index of learning styles questionnaire. Retrieved on 9 April 2014, from http://www4.ncsu.edu/unity/lockers/users/f/felder/public/ILSdir/ILS-nondisclosure.html

Honey, P., \& Mumford, A. (1992). The Manual of Learning Styles. $3^{\text {rd }}$ ed. Maidenhead, UK: Peters Honey.

James, W. B., \& Blank, W. E. (1993). Review and critique of available learning-style instruments for adults. In D. Flannery (Ed.), Applying cognitive learning styles (pp. 47-58). San Francisco: Jossey-Bass.

Nasution, S. (2011). Berbagai pendekatan dalam proses belajar \& mengajar, Jakarta: Bumi Aksara.

Nurcahya. (2006). Pengaruh partisipasi mahasiswa dalam organisasi terhadap pengelolaan belajar mahasiswa Jurusan Pendidikan Teknik Bangunan FPTK UPI. FPTK UPI Bandung.

Pabundu, Moh. (2010). Budaya Organisasi dan Peningkatan Kinerja Perusahaan. Jakarta: PT Bumi Aksara.

Pujiningsih, Sri. (2009). Pengaruh faktor preferensi gaya belajar terhadap prestasi belajar mahasiswa Akuntansi. Universitas Negeri Malang.

Purwiana, Rina, \& Rohayati, Suci. (2016). Pengaruh gaya belajar dan lingkungan belajar terhadap prestasi belajar mahasiswa Program Studi Pendidikan Akuntansi Fakultas Ekonomi Universitas Negeri Surabaya.

Riding, R., \& Cheema, I. (1991). Cognitive styles: An overview and integration. Educational Psychology: An International Journal of Experimental Educational Psychology, 11(3-4), 193-215.

Sapuri, Rafy. (2009). Psikologi Islam Tuntunan Jiwa Manusia Modern. Jakarta: Raja Grafindo Persada.

Sardiman, A.M. (2001). Interaksi dan Motivasi Belajar Mengajar. Jakarta: PT. Raja Grafindo Persada.

Syofyan, Rita. (2010). Pengaruh sosial ekonomi keluarga, partisipasi dalam organisasi kemahasiswaan dan komunikasi interpersonal dengan dosen terhadap prestasi belajar mahasiswa PSPE. Universitas Negeri Padang.

Tanta. (2010). Pengaruh gaya belajar terhadap hasil belajar mahasiswa pada mata kuliah Biologi Umum Program Studi Pendidikan Biologi Universitas Cenderawasih. Universitas Cenderawasih.

Triana, Endah. (2013). Pengaruh keaktifan berorganisasi dan kebiasaan belajar terhadap prestasi belajar mahasiswa Jurusan Pendidikan Geografi Angkatan 2008 dan 2009 Universitas Negeri Yogyakarta. Universitas Negeri Yogyakarta. 